\title{
Lake Ladoga digital bathymetric models: development approaches and insight for limnological investigations
}

\author{
Mikhail A. Naumenko \\ Institute of Limnology of Russian Academy of Sciences, Sevastiaynov 9, Saint Petersburg, 196105, Russian Federation, \\ e-mail: m.a.naumenko@mail.ru,m.naumenko@limno.org.ru
}

\begin{abstract}
The creation of digital bathymetric models (DBM) of lakes allows not only for storage of the data on depths and shorelines in a standard format, but also for the estimation of the major morphometric characteristics of the reservoirs. To calculate the water, thermal, and chemical budgets of large lakes, it is important to know their hypsometry. We developed a new digital model of Lake Ladoga, the largest European lake, which was done to identify and correct topographic data errors, as well as to identify more depth points. The produced bathymetric model of the lake allowed for the updating of morphometric characteristics. The lake-bottom grid of $0.5 \times 0.5 \mathrm{~km}$ with 70190 depth points of interest was produced using the kriging procedure with the mean error $\mathrm{ME}=0.05 \mathrm{~m}$ and root mean square error $\mathrm{RMSE}=5.6 \mathrm{~m}$. The statistical characteristics of the lake depth and slope are determined on the basis of the advanced digital model of the lakebed relief. The form of the lake depression corresponds to the convex type (microtype) and bears some similarity to lakes Erie, Huron, Vanern, and Malaren. We describe how the bathymetric model has been developed and the morphometric characteristics of the lake have been corrected. We also discuss the results of its application in limnological investigations. A relationship has been established between surface water temperature, transparency and the bottom depths for the various seasons of Lake Ladoga.
\end{abstract}

Key words: digital bathymetric models, morphometric characteristics, application in limnological investigations, Lake Ladoga

\section{Introduction}

Accurate quantitative description of the morphometric characteristics of a large lake, including the basin form and depth distribution, is of importance for understanding morphology and bottom surface roughness (Håkanson 1981, 2005). Geological and tectonic mapping of a lake bottom is impossible without bathymetric maps that provide detailed spatial and temporal insights into the locations of landforms, their contours and boundaries, position, and relationship to objects (Smith et al. 2011; Lecours et al. 2016). Furthermore, conventional bottom topographic surveys are a key tool for the study of the thermal and light regime, wave processes, and the processes responsible for the resuspension of sediment material as well as its accumulation in different regions (Håkanson and Jansson 1983).

Heterogeneity of lake depth can result in sig- nificant horizontal heterogeneities in the physical and chemical properties of water bodies (Tilzer and Serruya 1990). Bottom topography largely governs the distribution of river water in a lake, especially the dynamics of the bottom layers, and in combination with the lake length and width of the body, determines its surface and internal seiche parameters (Vidal et al. 2013). The shape and size of the lake depressions are responsible for the timing of freeze-up and break-up in certain areas, as well as for the duration of different stages of ice cover (Elo 2007). It is known that interactions between the lake surface water, the ice, and the atmosphere influence local weather conditions and climate on the regional scale. Hence, with increased horizontal resolution in numerical weather forecast models, the role of the local coverage of lakes becomes more significant. To take into account the impact of lakes on climate and weather, atmospheric models need to be coupled with specific lake models that 
calculate surface fluxes depending on the state of lakes (Kourzeneva et al. 2012). The lake depth is a necessary parameter of any lake model. Likewise, the 3D-thermodynamic model of any lake also requires a bathymetric model as input. Knowledge of a lake's bathymetry is required for observation management, limnological classification, prediction of most processes in the lake, and to explore hydrobiological processes (Salmaso et al. 2003). Moreover, if remote sensing information is applied to the study of the lake surface, it is necessary to compare the signal with the depth distribution. Therefore, a more advanced investigation was needed to provide a sophisticated description of the bottom relief of Lake Ladoga.

Today, the most promising method to study the morphometry of large lakes is to create digital models (Florinsky 2016; Chaplot et al. 2006; Heritage et al. 2009). Building digital bathymetric models (DBM) is based on the use of nautical maps and the creation of digital datasets of depths and their coordinates, which are applied for obtaining depths in equidistant grid cells. Thus, the development of numerical representations of lake bottom topography is one of the important challenges of limnological studies. There are several DBM's of the world's largest lakes; bathymetric gridded data and digitized shorelines have been compiled for the five Great Lakes (Lake Superior, Lake Michigan, Lake Huron, Lake Erie, Lake Ontario) and Lake St. Clair. These bathymetric grids display the average lake depths in 2-km squares (1.2-km squares for lake St. Clair) (Schwab and Sellers 1980). The new advanced version of digital bathymetry of Great Lakes can be found on the NOAA website (NOAA 2020). DBMs of Lake Tahoe (Gardner et al. 2000) and Great Slave Lake (Schertzer 2000) were created at the turn of the 20th and the 21 st century. A bottom topography of subglacial Lake Vostok was created in 2010 (Masolov et al. 2010). The depth distribution of Lake Onega, the second largest lake in Europe, was digitized in 2000 with a spatial resolution of $0.6 \mathrm{~km}$, allowing for an adjustment for the volume of water in the lake (Naumenko 2000). Digital bathymetric models of Lake Baikal (Sherstyankin et al. 2006) and Lake Teletskoe (Selegei et al. 2001) have been used for multipurpose investigations. A wellstructured lake bottom morphology has been illustrated by a new bathymetric map of the "Haut-Lac" of Lake Geneva (Sastre et al. 2010). A digital map of Lake Balkhash was created at a scale of 1:500 000 in 2014 (Tursunov et al. 2014). Recently a DBM of European Lake Ilmen was produced, and the lake morphometric characteristics were updated with estimates of its volume variation depending on the water level (Naumenko et al. 2015).

The first digital bathymetric model of the largest European lake - Lake Ladoga - was presented at the First Lake Ladoga Symposium in St. Petersburg in 1993 (Sorokin et al. 1996). This model has been used for two decades in the course of thermal, hydrophysical investigations and regionalization of the lake.

The main objective of this paper is to present the current state of digital bottom modeling of Lake Ladoga and an overview of existing Lake Ladoga DBMs. The work provides a description of how the bathymetric model has been developed and the morphometric characteristics of the lake corrected. An overview of Lake Ladoga bathymetric models demonstrates the importance its application to limnological investigations. Some appropriated examples are discussed.

\section{Study area and data}

\section{Description of Lake Ladoga}

The largest European lake, Lake Ladoga, is almost submeridionally elongated and lies between $60^{\circ}$ and $62^{\circ} \mathrm{N}$ in North-West Russia (Fig. 1). It ranks as the 18th largest lake in the world by area, and as the 14th largest by volume (Herdendorf 1982). The bottom of Lake Ladoga features a pattern typical of an intracontinental glacial shelf with previous tectonic uplift. From the geological point of view, the main feature of the lake bottom is its location on the boundary of two geological structures: the Russian plate and the Baltic crystalline shield (Subetto et al. 1998), which determine differences of the depth distribution in the lake. The southern part is shallower, with a depth of 5 to 20 meters, whereas the northern area of the lake is much deeper, with depths varying between 100 and 200 meters. The lake's maximum depth, 230 meters, lies in this region. Lake Ladoga lies 5.1 meters above sea level, and although its annual water level fluctuates by 0.7 $m$ on average each year, the year-to-year monthly mean magnitude of the level range can reach 


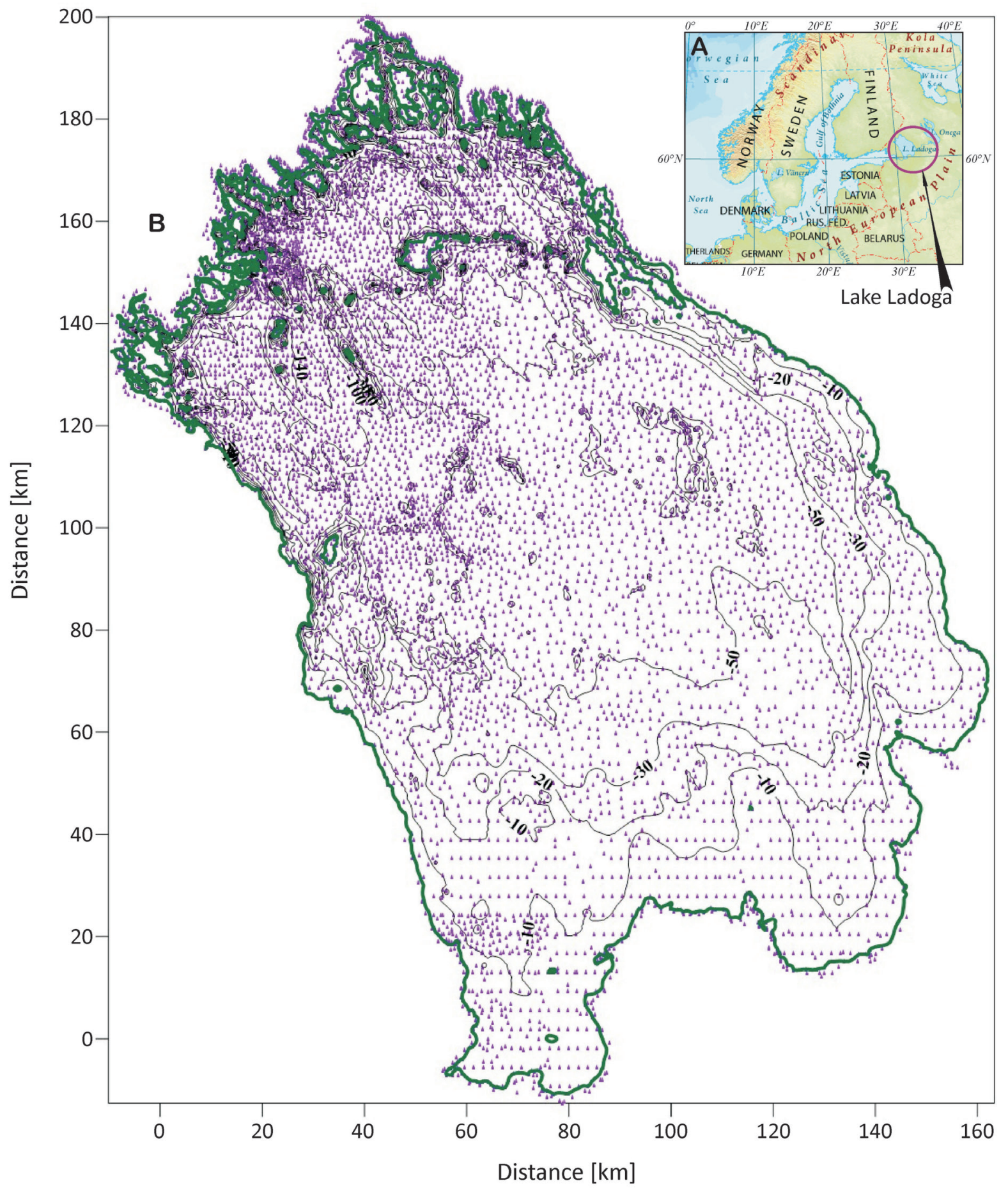

Fig. 1. Position of Lake Ladoga in geographical coordinates (A), bathymetric depth and location of depth points used for creation of the DBM (B). 10, 20, 30, 50, and100-m isobaths are drawn

about $3 \mathrm{~m}$. Mean residence time is approximately 11 years, and its main outlet, the Neva River, flows out from the lake with a mean annual exchange of about $2500 \mathrm{~m}^{3} \mathrm{~s}^{-1}$. Lake Ladoga is located in the boreal temperate zone, is dimictic, and experiences a mean annual air temperature of $3.4^{\circ} \mathrm{C}$, normally keeping its ice cover for five months of the year. A comprehensive overview of the catchment and limnology of Lake Ladoga can be found in the monograph edited by Rumiantsev and Drabkova (2002). 
Data used

An estimation of morphometric characteristics of Lake Ladoga was carried out in the 1960's by Chern'yeva (1966) using the conventional planimetric method and nautical paper maps of 1964 . State-of-the-art maps of Lake Ladoga's depths have been essentially updated and have none of the "white" spots that used to exist in certain regions of the original maps. The use of modern computer techniques has been successful in morphometric calculation of the lake and should be used in the future. Digital bathymetric modeling determines the position of the earth's surface relative to the three spatial coordinates $(X, Y, Z)$. To digitize the bottom depths for the first time we used official nautical maps with the scale 1:250000 and 1:100000 for the creation of digital files on depths with their coordinates (Naumenko 1995). Of the bathymetric data, 7,815 point sites were of digitized shorelines of the lake and its islands. A proxy digital model was used for calculation of the morphometric characteristics of Lake Ladoga with a spatial resolution of $0.8 \mathrm{~km}$. For the sake of further developing the digital model of Lake Ladoga, new digitizing has been carried out to identify and correct topographic data errors and to increase the quantity of depth points (Fig.1). To date, the quantity of points in the initial lake depth data used for the new lake model has grown by $24.4 \%$ in comparison with the earlier version. Some of the points were taken from the contour lines on nautical maps. 893 data points were selected from the ground above shorelines for accurate estimation of near-shore depths in the digital bathymetric model of Lake Ladoga. The shorelines of 78 significant islands, most of which are situated in the deep zone of the lake and influence local morphometric characteristics, were digitized and included in the data sets. This has since been updated, as there are over 500 islands in Lake Ladoga with a total area of about $435 \mathrm{~km}$. (only 2.4\% of the lake's surface area). Several of them are located in the near-shore zone and add to the lake's coastal line. The northern part of Lake Ladoga presents a more complex distribution of depths than the central and southern parts, and it is the northernpart in which the depth amplitudes are the largest in comparison with other lake areas. Chaplot et al. (2006) confirmed that if measurement data are sparse in regions of high topographic variation then the topography is generally poorly modeled by the interpolator. Therefore, more data are needed where there are relatively significant elevation changes over short distances. Conversely, fewer points are required for more flat surfaces. The survey strategy is important and should be sensitive to the morphology under consideration (Florinski 1998; Heritage et al. 2009). We used this concept to select depth points, especially in the northern part of Lake Ladoga. The general statistics of bathymetric data and shoreline record in the database of depths for Lake Ladoga were computed from the initial set of data (Table 1).

\section{Methods}

\section{Calculation}

The geographic coordinates taken from the original maps were converted into metric values for correct calculation of the lake areas and volumes. The formulas of Krasovskii (1942) were used for sufficiently accurate geographical-to-metric coordinate transformation. Digital bathymetric models of lakes are commonly adopted to represent bottom morphology in three dimensions. We used Surfer software (Golden Software, Inc.) for interpolation of point depth data to equidistant nodes. The kriging interpolation method was deliberately selected to calculate the depths. There have been many studies of the accuracy of interpolation techniques for the generation of digital elevation models (DEM) in relation to landform types and data quantity or density, for instance (Chaplot et al. 2006). Some studies indicate that among many existing interpolation techniques, geostatistical ones perform better than others. More detailed mathematical description with regard to precision and accuracy are beyond the scope of the present paper.

The main goal of our calculation was to choose a more accurate grid scale and build a more precise model based on the new data set for Lake Ladoga (Naumenko 2013). For identification of the optimal grid scale $\left(G_{s}\right)$ and radius interpolation $(R)$, we produced 49 DBM's of Lake Ladoga with different $G_{s}$ values $(0.2,0.5,0.8,1.0,1.5,2.0 \mathrm{~km}$ and those that go by default) and $R$ values $(2,5,8,10$, $15,20 \mathrm{~km}$ and those by default). The DBM quality was assessed by calculating the mean error (ME) and the root mean square error (RMSE) between 
depths estimated by the interpolation technique at each point and observed bottom depths from nautical maps (Wise 2000, 2007):

$$
\begin{aligned}
& M E=\frac{1}{N} \sum_{i=1}^{n}\left(Z_{e s t}-Z_{\mathrm{obs}}\right), \\
& \operatorname{RMSE}=\sqrt{\frac{1}{N} \sum_{i=1}^{n}\left(Z_{\text {est }}-Z_{\mathrm{obs}}\right)^{2}},
\end{aligned}
$$

where: $Z_{\text {est }}$ - estimated bottom depth, $Z_{\text {obs }}$ observed bottom depth.

The ME and RMSE values varied from 0.02 to $0.55 \mathrm{~m}$ and 2.5 to $15.4 \mathrm{~m}$ respectively. The area of Lake Ladoga, which was calculated by the planimetric method (Chern'yeva 1966), took into account chosen appropriate parameters, as well as isobaths positions. Thus, the grid scale $G_{s}=0.5 \mathrm{~km}$ and radius interpolation $R_{1}=8 \mathrm{~km}$ are optimal ones with $M E=0.05 \mathrm{~m}$ and $\mathrm{RMSE}=5.6 \mathrm{~m}$. It should be noted that maximal errors were on the steepest slope of the bottom. Therefore 70,190 depth points of interest were produced for a grid of $455 \times 444$ nodes after the blanking of the Lake Ladoga shoreline.

\section{Comparison of DBMs and traditional method}

The undoubted advantage of digital models for computing the area and volumes of large lakes lies in the ability to calculate morphometric parameters for any isobath. For Lake Ladoga, the area and volumes are counted through every meter of depth. Moreover, calculations are not very timeconsuming compared to the traditional method. It is interesting and useful to compare morphometric parameters which have been calculated by traditional cartographic methods, with those obtained from a DBM (Table 2). The solid geometry formula for calculating the volume of frustum of a circular cone has been applied by limnologists to compute lake volumes.

The volume $V$ of water $\left(\mathrm{km}^{3}\right)$ can be estimated as:

$$
V=\frac{1}{3}\left[\Delta z \times\left(S_{1}+S_{2}+\sqrt{S_{1} \times S_{2}}\right)\right],
$$

where: $\Delta z$ - difference in depth between two successive depth contours in $\mathrm{km}, S_{1}$ - area of the lake within the outer depth contour under consideration in $\mathrm{km}^{2}, S_{2}$ - area of the lake within the inner contour line under consideration in $\mathrm{km}^{2}$.

Three variants of values of area and volume of
Lake Ladoga provide evidence of insignificant differences in the upper horizons of the lake, whereas in the deeper areas the reduction of volumes is considerable compared to the planimetric method. The area and volume variations, represented in percent values, are relative values to the latest DBM (LDBM) model. The numbers from this model were compared to those of the planimetric method (column 8 and 9 in Table 3) and of the first version of the DBM (column 10 and 11 in Table 3). Formula of a simple rank order was used:

$$
R=\frac{(Q L D B M-Q)}{Q L D B M} \times 100,
$$

where: $R$ - rank compared to the latest DBM model (LDBM), and $Q$ is $S$ - area (planimetric method / first version of DBM) or $V$ - volume (planimetric method / first version of DBM).

The "+" sign means an increase in area/ volume, and " - " sign means reduction, respectively. It can be seen that the planimetric method overstates both the area of the lake regions and the volumes. This is especially obvious for volume computations, the larger the thickness of the layer one choses, the greater the error in determining its volume can be. As for the estimation of the volume of Lake Ladoga, the difference in volume between two depth contours is extremely significant in the case of the planimetric method. Within the layer of 20-50 $\mathrm{m}$ the DBM volumes became smaller than the volumes obtained by the solid geometry methods (Table 3 ). This can be clearly observed for the range of 50-100 m, where the bottom relief sharply differs from the shallow part to the deeper area (Fig. 1) where the depths and bottom slope increase. Differences in areas and volumes between the two models are not large, although the total amount of initial depth data in the latest version of the model has been increased by $24.4 \%$. This additive did not fundamentally change the morphometric parameters of Lake Ladoga. The insignificant increase of the latest DBM volume from 838 to $848 \mathrm{~km}^{3}$ (about $1 \%$ ) (Table 3 ) is associated with a more precise grid size due to the addition of new depth points. This can be explained by equivalent regular spacing between observations $E S(\mathrm{~m})$ by the formula:

$$
E S=\sqrt{S / N},
$$

where: $S$ is the lake surface area in $\mathrm{m}^{2}$ and 
Table 1. Lake Ladoga bathymetric data and shoreline record statistics

\begin{tabular}{ccccccc}
\hline \multirow{2}{*}{ Characteristics of bathymetric and shoreline data } & \multicolumn{5}{c}{ Basic statistics of the depth Z } \\
\cline { 2 - 7 } & Min & Max & Avg & Med & SD & CV \\
\hline $\begin{array}{c}\text { Total number of bathymetric data, land height and } \\
\text { shoreline points } \mathrm{N}=9855\end{array}$ & -233 & 93 & -46.9 & -36.0 & 49.6 & 1.06 \\
$\begin{array}{c}\text { Number of bathymetric data and shoreline points } \\
\mathrm{N}_{1}=8962\end{array}$ & -233 & 0 & -52.5 & -46.5 & 48.4 & 0.92 \\
\hline
\end{tabular}

Table 2. Lake Ladoga area and volume calculation by different methods and comparison of these results

\begin{tabular}{|c|c|c|c|c|c|c|c|c|c|c|}
\hline \multirow{3}{*}{$\begin{array}{l}\text { Depth } \\
\text { Z [m] }\end{array}$} & \multirow{2}{*}{\multicolumn{2}{|c|}{$\begin{array}{l}\text { Planimetric } \\
\text { method }\end{array}$}} & \multirow{2}{*}{\multicolumn{2}{|c|}{$\begin{array}{c}\text { First DBM version } \\
\text { grid size } \\
0.8 \times 0.8 \mathrm{~km} \\
\mathrm{ES}=1.6 \mathrm{~km}\end{array}$}} & \multirow{2}{*}{\multicolumn{2}{|c|}{$\begin{array}{l}\text { Last DBM version } \\
\text { grid size } \\
0.5 \times 0.5 \mathrm{~km} \\
\text { ES }=1.4 \mathrm{~km}\end{array}$}} & \multicolumn{4}{|c|}{ Relative variation } \\
\hline & & & & & & & \multicolumn{2}{|c|}{$\begin{array}{l}\text { for planimetric } \\
\text { method }\end{array}$} & \multicolumn{2}{|c|}{$\begin{array}{l}\text { for first version of } \\
\text { DBM }\end{array}$} \\
\hline & $\mathrm{S}\left[\mathrm{km}^{2}\right]$ & $\mathrm{V}\left[\mathrm{km}^{3}\right]$ & $\mathrm{S}\left[\mathrm{km}^{2}\right]$ & $\mathrm{V}\left[\mathrm{km}^{3}\right]$ & $\mathrm{S}\left[\mathrm{km}^{2}\right]$ & $\mathrm{V}\left[\mathrm{km}^{3}\right]$ & $\mathrm{S}$ [\%] & V [\%] & S [\%] & V [\%] \\
\hline 1 & 2 & 3 & 4 & 5 & 6 & 7 & 8 & 9 & 10 & 11 \\
\hline 0 & 17678 & 908 & 17850.8 & 837.9 & 17765.4 & 847.8 & 0.5 & -6.6 & -0.5 & 1.2 \\
\hline-5 & 16438 & 823 & 16096.0 & 753.1 & 16109.3 & 763.4 & -2.0 & -7.2 & 0.1 & 1.4 \\
\hline-10 & 14825 & 744 & 14624.1 & 676.3 & 14619.0 & 686.5 & -1.4 & -7.7 & 0.0 & 1.5 \\
\hline-20 & 11925 & 613 & 11932.8 & 545.7 & 11912.0 & 555.5 & -0.1 & -9.4 & -0.2 & 1.8 \\
\hline-50 & 8098 & 315 & 7632.3 & 256.5 & 7669.1 & 264.1 & -5.3 & -16.2 & 0.5 & 3.0 \\
\hline-100 & 2226 & 72 & 2090.1 & 61.1 & 2065.7 & 61.4 & -7.2 & -14.7 & -1.2 & 0.5 \\
\hline-150 & 461 & 12 & 395.5 & 7.2 & 395.5 & 7.6 & -14.2 & -36.7 & 0.0 & 5.6 \\
\hline-200 & 24 & 1 & 13.8 & 0.1 & 17.1 & 0.1 & -28.8 & -90.0 & 23.9 & 0.0 \\
\hline
\end{tabular}

Table 3. Volume differences between depth layers calculated by different methods

\begin{tabular}{cccc}
\hline \multirow{2}{*}{ Stratum, $\Delta z[\mathrm{~m}]$} & \multicolumn{3}{c}{ Volume of the stratum, $\Delta \mathrm{V}\left[\mathrm{km}^{3}\right]$} \\
\cline { 2 - 4 } & Planimetric method & First version of DBM & Last version of DBM \\
\hline $0-5$ & 85 & 84.8 & 84.5 \\
$5-10$ & 79 & 76.8 & 76.8 \\
$10-20$ & 131 & 130.6 & 131.1 \\
$20-50$ & 298 & 289.2 & 291.4 \\
$50-100$ & 243 & 195.4 & 202.7 \\
$100-150$ & 60 & 53.8 & 53.8 \\
$150-200$ & 11 & 7.2 & 7.5 \\
\hline
\end{tabular}


$N$ is the number of the points respectively. In fact, ES in the latest DBM variant became less than the one in the first DBM by $0.2 \mathrm{~km}$. Thus, the horizontal resolution of the DBM has improved, and finally the latest DBM has been approved to update the morphometric characteristics of Lake Ladoga.

\section{Results}

\section{Basic morphometric variables of Lake Ladoga}

Figure 2 shows the bathymetry and bottom slope (steepest slope) of Lake Ladoga from the latest DBM available. The maximum depth and bottom slope are in the northern part of the lake. Basic morphometric characteristics of Lake Ladoga were also calculated using the most recent DBM, particularly slopes of the lake floor, which are extremely difficult to obtain by planimetric mapping methods (Table 4). The lake volume was calculated by integration from the surface to the bottom based on the actual depth contour instead of based on strata, as usually done when lake volumes are evaluated by

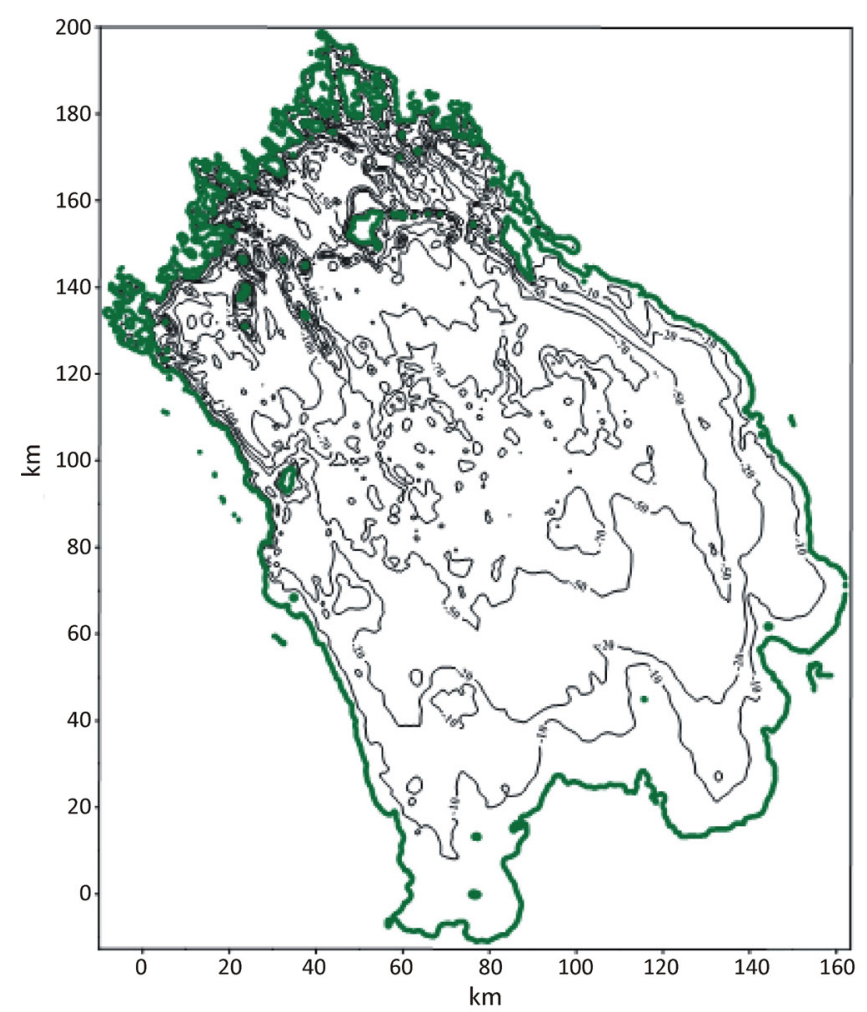

the planimetric method. This approach allowed a more accurate calculation with consideration to the roughness of the lake bottom.

Corresponding relationships, histograms of depths and slopes, type of the lake basin form

For estimation of the water, thermal, and chemical budgets of Lake Ladoga, we calculated and graphed the depth-area and depth-volume relationships with a depth interval of 1-5 m to learn the variations of the lake area and volume depending on the depth (Fig. 3A).

An important descriptor of Lake Ladoga is a histogram of the bottom depths with respect to the shape of the depression and the distribution function of the lake bed. It has two modes, which indicate the prevalence of the two characteristic depth ranges: $0-18 \mathrm{~m}$ in the shallow area and $50-70 \mathrm{~m}$ in the shoulder area of the lake (Fig. 3B).

The crypto-depression of Lake Ladoga (the lake basin, the floor of which lies below sea level) is 16080.2 (90.5\%) km² in area and $761.8 \mathrm{~km}^{3}$ (89.9\%) in volume. The littoral zone (the zone in which high-

Fig. 2. Bottom depth in meters (left) and slope distribution in degrees in Lake Ladoga (right) 
Table 4. Basic morphometric variables of Lake Ladoga and statistical parameters of the DBM

\begin{tabular}{|c|c|}
\hline Variable / parameter & Value \\
\hline Altitude above sea level [m] & 5.1 \\
\hline Drainage area, DA $\left[\mathrm{km}^{2}\right]$ & $258600^{(1)}$ \\
\hline Total lake area, $\mathrm{S}_{\text {tot. }}\left[\mathrm{km}^{2}\right]$ & 18135 \\
\hline Lake area, $\mathrm{S}\left[\mathrm{km}^{2}\right]$ & 17765.4 \\
\hline Island area, I [km²] & 456.6 \\
\hline Area index* [dimensionless] & 0.07 \\
\hline Volume, $\mathrm{V}\left[\mathrm{km}^{3}\right]$ & 847.8 \\
\hline Mean depth, $\mathbf{z}_{\text {mean }}[\mathrm{m}]$ & 48.3 \\
\hline Median depth, $z_{50}[\mathrm{~m}]$ & 41.6 \\
\hline Standard deviation of depth [m] & 39.9 \\
\hline Coefficient of skewness & 1.06 \\
\hline kurtosis & 22.92 \\
\hline variation & 0.82 \\
\hline Maximum depth, $\mathbf{z}_{\max }[\mathrm{m}]$ & 230 \\
\hline Maximum length, $\mathrm{L}_{\max }[\mathrm{km}]$ & $219^{(2)}$ \\
\hline Maximum width, $\mathrm{B}_{\max }[\mathrm{km}]$ & $125^{(3)}$ \\
\hline Relative depth $^{* *}, \mathrm{z}_{\mathrm{r}}[\%]$ & 0.15 \\
\hline Depth index ${ }^{* * *}, v$ [dimensionless] & 0.07 \\
\hline Direction of major axis & NNW-SSE \\
\hline Shoreline length, $\mathrm{l}_{\mathrm{o}}[\mathrm{km}]$ & $1570^{(2)}$ \\
\hline Shore development ${ }^{* * *}, \mathrm{D}$ [dimensionless] & 3.28 \\
\hline Capacity factor, $\mathbf{z}_{\text {mean }} / \mathbf{z}_{\max }$ & 0.21 \\
\hline Form factor ${ }^{* * * * *}, \mathrm{~K}$ [dimensionless] & 0.38 \\
\hline Water residence time, WRT [years] & $\sim 11$ \\
\hline Mean slope, $\gamma_{\text {mean }}[$ degree] & 0.49 \\
\hline Median slope, $\gamma_{50}$ [degree] & 0.20 \\
\hline Standard deviation of slope, $\gamma$ [degree] & 0.76 \\
\hline Coefficient of skewness $\gamma$ & 3.62 \\
\hline kurtosis $\gamma$ & -15.11 \\
\hline variation $\gamma$ & 1.55 \\
\hline Maximum slope, $\gamma_{\max }$ [degree] & 11.8 \\
\hline
\end{tabular}



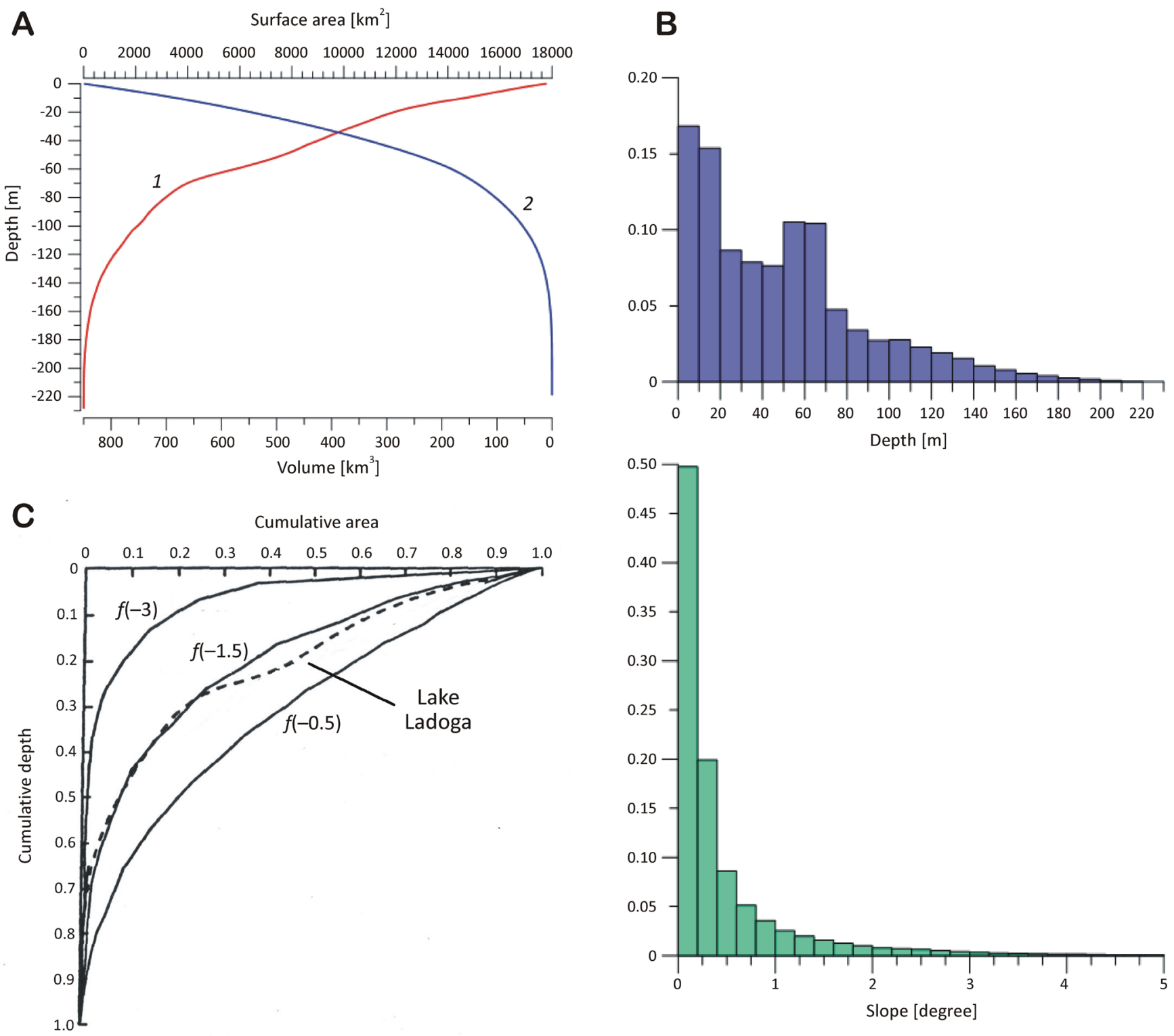

Fig. 3. Lake Ladoga depth-area (curve 1) and depth-volume (curve 2) relationships (A); histogram of Lake Ladoga depth (upper panel) and bottom slope (lower panel) (B); relative hypsographic curves for various convex types of lake depression by Håkanson (1981) (very convex: $f(-3.0)-f(-1.5)$; convex: $f(-1.5)-f(-0.5))$ and Lake Ladoga relative hypsographic curve (C)

er aquatic vegetation grows to the depth of $8 \mathrm{~m}$ ) has the area $S_{\text {lit. }}=2543.0 \mathrm{~km}^{2}$ and the volume $V_{\text {lit. }}$ $=9.67 \mathrm{~km}^{3}$.

Krause and Menard (1965) showed that the bottom depth distribution function can be described by calculating the first depth derivative, namely the bottom slope. For the first time we calculated the magnitude of the greatest slope steepness $\gamma$ in each node of the Lake Ladoga digital model. The average slope of the lake bottom $\left(0.49^{\circ}\right)$ is comparable with the average slope of the lake catchment. It should be noted that the slope gradient depends on the grid size and can be underestimated. Estimation of the bottom slope on a more detailed grid demonstrates much higher values (more than 20 degrees). The slope can have significant modifying effects on sediment distribution because it is an important determinant of turbidity currents that have an impact on sediment transport to deeper regions (Blais and Kalff 1995).

A histogram of the underwater relief slope of the lake characterizes a unimodal distribution func- 
tion with significant asymmetric displacement of the maximum in the range of small values. The distribution function of slope in the lake obeys $\chi^{2}-$ the distribution function. The maximum of the bottom slope is especially important in the diagnostics of the possibility of underwater landslides.

The definition of the lake form was carried out based on the representations of Håkanson (1981) (Fig. 3C). The Lake Ladoga depression belongs to the convex type (microtype), and from this point of view the lake form is similar to lakes Erie, Huron, Vanern and Malaren. The area with the depth range between $35-60 \mathrm{~m}$ or $0.15-0.30$ is less convex than other areas (Fig. 3B). Once again it confirms the above conclusion that the planimetric method is not correct in the case of volume calculation for a large range of depth. Indeed, a big difference in volume exists, in the range of 20-50 and 50-100 m.

\section{Applying DBM to limnological investigation}

We will give several examples of using the bathymetric model of Lake Ladoga to establish dependencies between limnic parameters and the distribution of bottom depths. Thematic databases, along with equidistant bottom depths, made it possible to correctly and simply obtain the new necessary quantitative relationships for understanding the ecosystem of Lake Ladoga.

Lake level and relevant volume and area

Detailed digital maps of a lake bottom are used for many purposes, among which are comprehensive resource management plans, environmental impact assessments, limnological and geomorphological investigation. Knowledge of the relationship of the level and volume of Lake Ladoga and the mean discharge of the Neva River is a useful tool in the light of ever-increasing environmental issues. This relationship can help to estimate area and volume under varying lake levels (Fig. 4). Moreover, a clear link exists between Neva River water exchange and the level of Lake Ladoga.

Heat content of Lake Ladoga

More than 60 years ago it was shown that annual heat budgets in temperate lakes result from their morphometric characteristics (Gorham 1964). Ideally, the heat storage in a lake $(Q)$ is computed from detailed information on the lake bathymetry and spatially representative vertical temperature profiles to derive the lake heat content ( Ambrosetti and Barbanti 2002; Schertzer et al. 2003) using the formula:

$$
\mathrm{Q}=\iiint_{0}^{V} c \rho T \partial V,
$$

where: $c$ - specific thermal capacity, $\rho$ - water density, $T$ - water temperature in ${ }^{\circ} \mathrm{C}$.

Along with the input of solar radiation, air temperature and wind the principal factor defining the temperature distributions in Lake Ladoga is its bathymetry, which partitions the lake into six distinct compartments. The limnological regions are delimited by isobaths $18,50,70,100$ and $140 \mathrm{~m}$ (Naumenko 1995). The digital bathymetric model has been applied to calculate the heat storage for the whole lake and its parts. It has enabled new calculations of seasonal climatological cycles of the water temperature and heat contents of Lake Ladoga to be carried out that allow for an examination of the thermal structure of the regions from January to

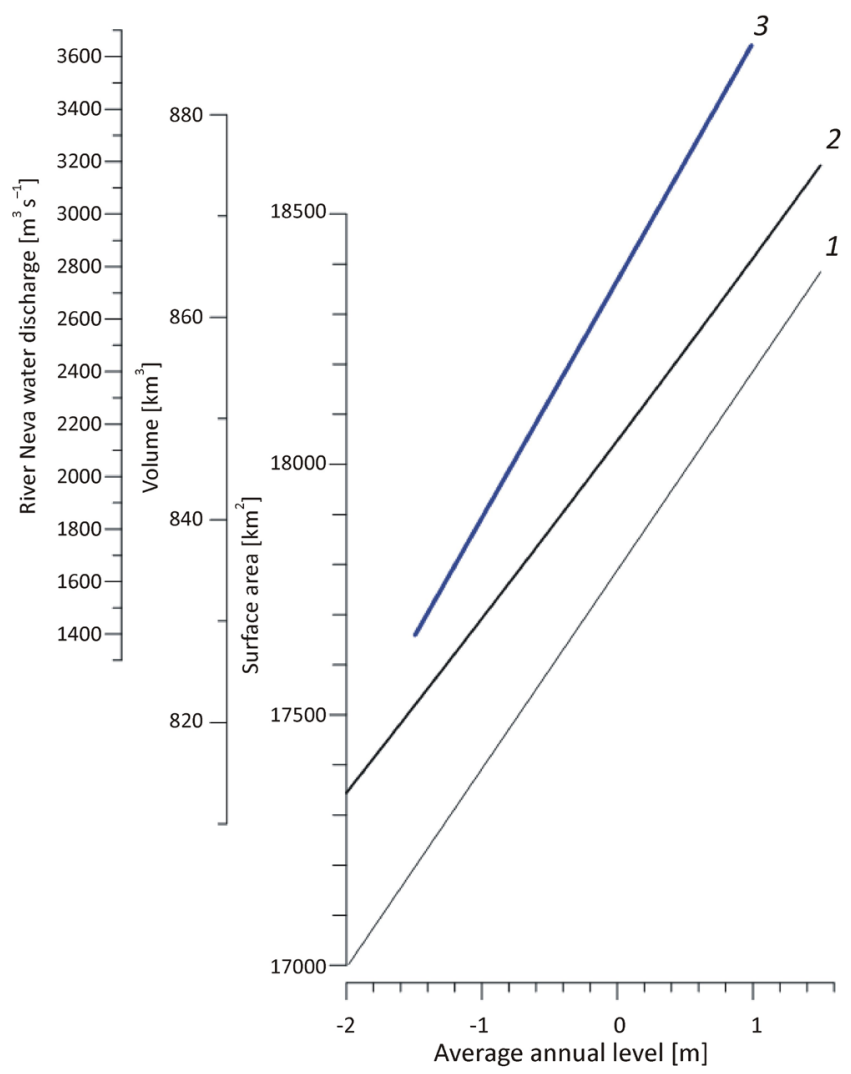

Fig. 4. Relationships between Lake Ladoga level and area (curve 1 ), and volume (curve 2), and exchange of River Neva (curve 3) 
December. We have found that the climatologically averaged surface temperature cycle in the open waters of Lake Ladoga can be accurately estimated for ten-day averaging with a lag of 5 days for all limnetic regions. This has allowed high-frequency temperature fluctuations to be smoothed. All of the data collected from the six limnetic regions from 1905 through 2003 was applied. Statistical analysis was used to calculate descriptive statistics (Naumenko and Guzivaty 2010).

The seasonal cycles of heat content for every limnetic region, region-wide mean temperature and mean whole lake temperature are shown in Figure 5, as well as whole lake heat content for a year. It clearly shows the gradual warming in the spring, the rapid rise to the summer maximum and the slow cooling in the fall. Owing to the large area of Lake Ladoga and its basin morphology, there is considerable horizontal and vertical heterogeneity in the temperature in all seasons except for the period of ice cover. Morphometric differences in the limnic regions of Lake Ladoga determine the specific conditions for heat accumulation and loss during the annual cycle, the timing of the beginning and end of hydrological seasons, and their duration. The mean annual lake-wide averaged water temperature is $3.7^{\circ} \mathrm{C}$ (Naumenko et al. 2007).

Relation of seasonal surface water temperature distribution and bottom depth

Obviously during the open-water period there is dependence between surface water tem-
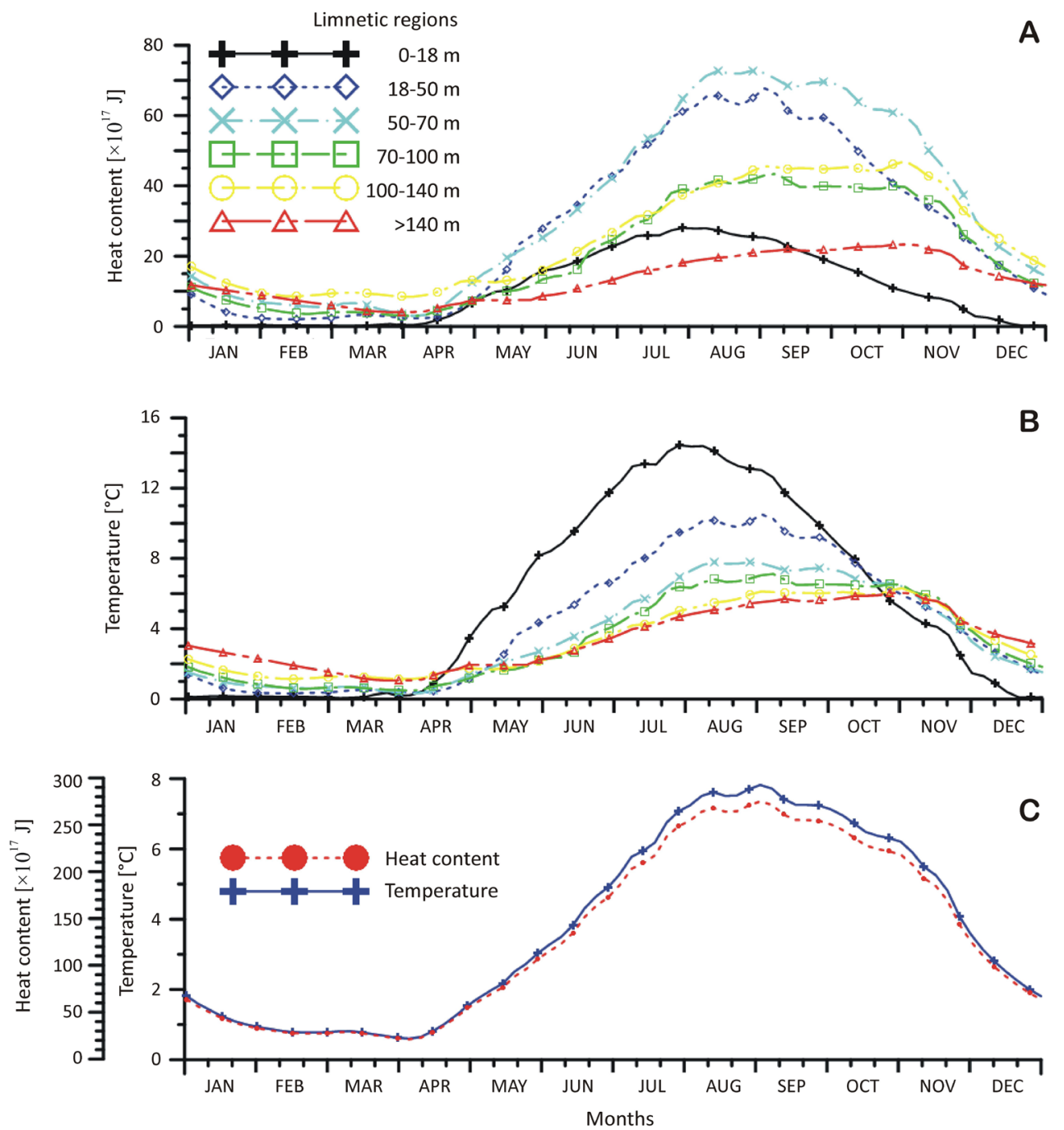

Fig. 5. Seasonal cycles of the thermal characteristics of Lake Ladoga regions (A, B) and whole lake (C) 
perature and depth distribution. The estimation of the power of morphometric influence on the spatial distribution of the water surface temperature, taking the season into account, is important for studying the evolution of the thermal state of a large lake surface and relevant limnological tasks. Naumenko et al. (2002) have produced a specific method and calculated the typical daily average spatial distributions of the water temperature in Lake Ladoga for any date during the ice-free period from mid-May to the beginning of November. The spatial distribution of water surface temperature in Lake Ladoga has been drawn over an equidistant grid with sides $10 \times 10 \mathrm{~km}$. The water surface temperature was presented for each date as a sum of two components: the determinate component, which is governed by the coordinates and bottom depth, and the random component, which strongly depends on the interaction with the atmosphere. The determinate surface temperature component was approximated by a full polynomial of the second order of coordinates $(x, y)$ and bottom depth $(z)$ of the certain square (curve 1 at Fig. 6):

$$
\mathrm{T}_{S}=f\left(\mathrm{x}, \mathrm{y}, \mathrm{x}^{2}, \mathrm{y}^{2}, \mathrm{xy}, \mathrm{xz}, \mathrm{zy}, \mathrm{z}^{2}\right) .
$$

The determination coefficients, which quanti- tatively define the correlation between these characteristics and water surface temperature, were calculated using the method of step-wise regression. In order to determine the pure influence of bottom depth on the water surface temperature, we also calculated the coefficients of linear correlation between them (curve 2 at Fig. 6).

The analysis of the seasonal variation in these coefficients indicates that depth has a determining influence on the evolution of the thermal state at the surface of Lake Ladoga from May to mid-July (Naumenko et al. 2002). During this period, from 60 to $80 \%$ of the total spatial temperature variance is governed by the coordinates and bottom depth. The direct influence of the depth is maximal in the first third of July and is equal to $60 \%$ of the variance. After establishment of stable thermal stratification in the entire lake, the spatial temperature inhomogeneity at the water surface becomes almost independent from the distribution of depth. During this period, the synoptic weather situation over the lake becomes determinative.

Monthly mean spatial transparency distribution and bottom depth in Lake Ladoga

The morphometric features of Lake Ladoga

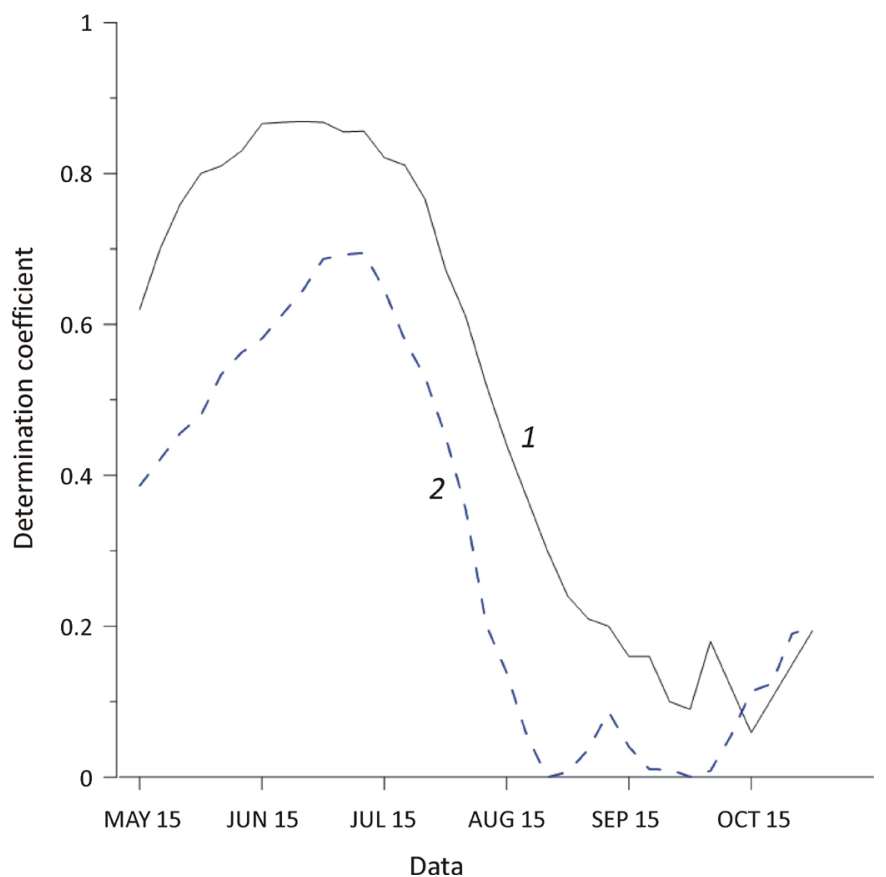

Fig. 6. Temporal course of determination coefficient between surface water temperature and the full polynomial of the second order of coordinates and bottom depth (curve 1) and only bottom depth (curve 2) 
and its thermal and dynamic regimes determine the distribution of total suspended matter (organic and inorganic) within the water body, which ultimately regulates the optical properties of the surface layer. The analysis was carried out based on the relationship of the spatial distribution of Secchi disk transparency and lake bottom depth (Naumenko 2008). To estimate the relationship between bottom depth distribution and spatial distribution of water transparency a polynomial approximation of the third degree was used. Secchi disk transparency was plotted as a function of bottom depth for the gridded points $(20 \times 20 \mathrm{~km}$ grid cell) on the graph in Figure 7 by using a digital morphometric model. It is evident that the value of the determination coefficient $R^{2}$ varies during the period of open water. The largest share of an explained dispersion (i.e. maximum $\mathrm{R}^{2}=64 \%$ ) described by this model was in May and decreased slightly in June.

In August, when the surface water temperature had reached maximum, the determination coefficient fell to less than $40 \%$. This indicates that spa- tial transparency distribution during that period was controlled more by hydrobiological and hydrodynamic factors than bottom depth distribution. After September the determination coefficient increased but did not reach the spring value. Polynomial approximation of the spatial transparency distribution allows the location of the maximum water transparency to be determined for each month. For May and June, water transparency with a value of more than $4 \mathrm{~m}$ occurred above the bottom depths over $100 \mathrm{~m}$. In August-September the maximum took place over depths of 60-80 m, i.e. in the central part of the lake. Therefore, the Secchi disk transparency is significantly correlated with the bottom depth in May-June when inshore surface water temperature and nutrients strongly affect spatial phytoplankton distribution and, in turn, water transparency.

\section{Discussion and conclusion}

The state and function of the modeling of the bathymetry of Lake Ladoga have been of great inter-

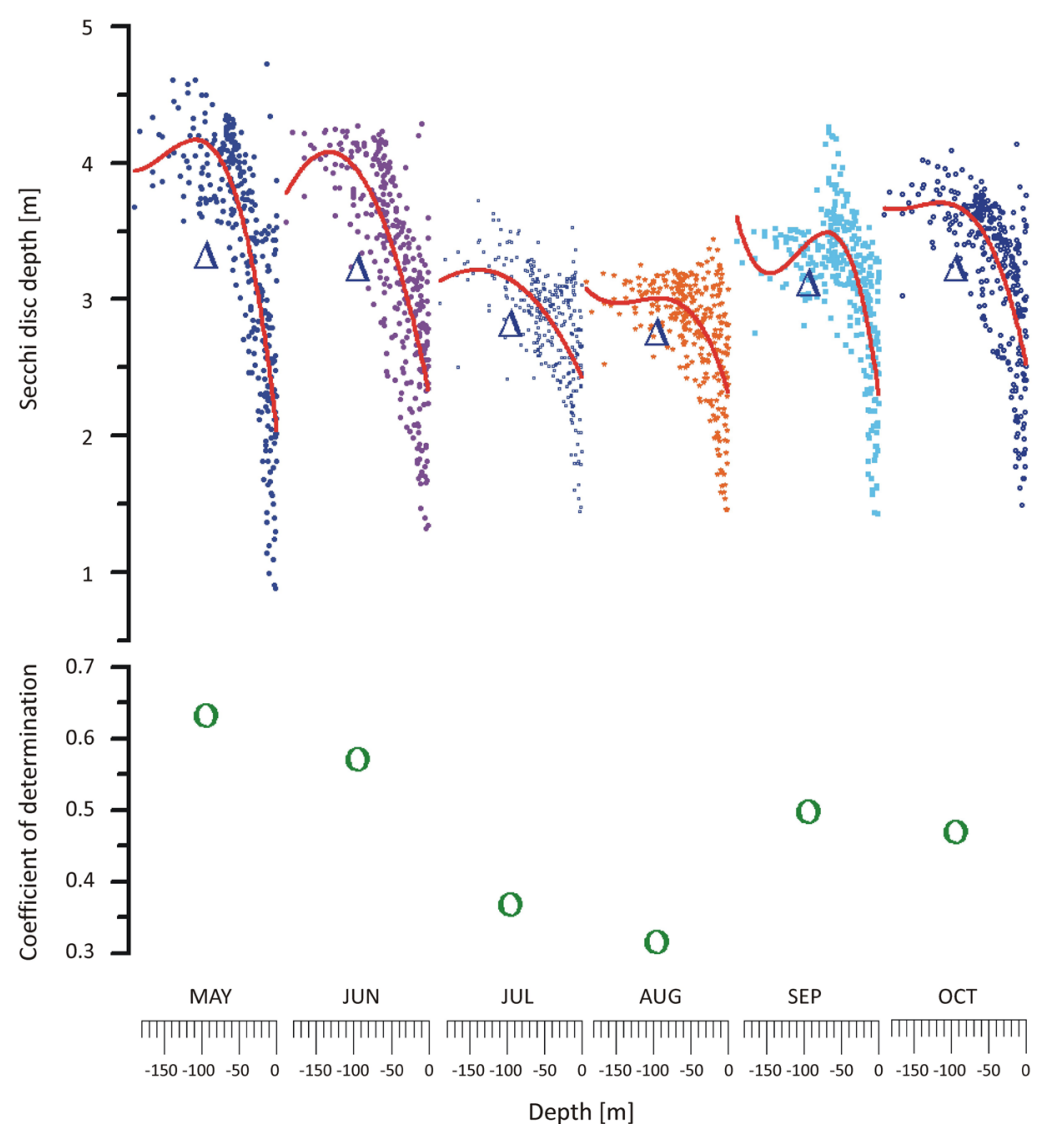

Fig. 7. Relation between monthly mean water transparency and depth distribution (upper) and the determination coefficient 
est in recent years due to progress in measurement and in calculation methods. Before the creation of the digital bathymetric model for Lake Ladoga, the quantitative characteristics of its depth distribution and of its bottom slopes in particular were rather limited, which held back the development of both limnological and geomorphological investigations of the spatial structure of the bottom relief. Evidently the Lake Ladoga bathymetric model is an effective and necessary tool for limnological studies.

The new bathymetric model of Lake Ladoga has allowed an estimation of major morphometric characteristics on the equidistant grid, and the updating of the hypsographic and volumetric curves. A three-dimensional image of the bottom relief of Lake Ladoga was shown for the first time (Naumenko 2015).The latest version of the digital model specified the lake volume more precisely in terms of the increase in the total number of points by $24.4 \%$ and the decrease of the mean minimum with respect to the nearest neighboring distance from $0.986 \mathrm{~km}$ to $0.923 \mathrm{~km}$. The new value of the volume of Lake Ladoga calculated on the model basis is equal to $848.8 \pm 2.4 \mathrm{~km}^{3}$, as opposed to the $908 \mathrm{~km}^{3}$ determined by the planimetric method by Chern'yeva (1966). The DBM technique rather than the planimetric one can be used for complicated morphometric calculations, for instance scour and fill volumes. Obviously, if the volume of a lake with the convex-type depression is calculated as a volume of a frustum of a circular cone adding a certain big depth range, the actual volume will be overvalued; we produced the same results when the Lake Onega bathymetric model was used for volume estimation. Since Lake Onega has the convex-type depression, the volume of the lake was overvalued to $298 \mathrm{~km}^{3}$ in comparison to $271.4 \mathrm{~km}^{3}$ (Naumenko 2000). The above considerations should be taken into account when making an assessment of water volume in water reservoirs. For water and heat storage assessment, digital bathymetric models are more accurate than, and preferable to, the traditional methods.

As pointed out by Blenckner (Blenckner 2005), landscape characteristics (including lake morphometry) and abiotic/biotic interactions play a key role in the control of the climate's effect on lake ecosystems. With the use of DBM we can easily illustrate the relationship of the level and volume of Lake Ladoga and the mean annual exchange of the Neva River, which is useful when studying ever-increasing environmental issues. The variation of the lake area and volume, as well as the Neva River exchange, should be taken into consideration in the case of climate change studies.

Studies of errors in the case of both digital elevation models and digital bathymetric models have consistently shown a link between various geomorphometric measures (such as the slope shape or steepness) and error (Wise 2000, 2007). The magnitude of error is found to vary systematically between convex, planar, and concave areas, and measures of terrain roughness. We also found that maximal depth errors, in the case of Lake Ladoga, were on the steepest slope of the bottom.

Our results indicate that the digital bathymetric model of Lake Ladoga with revised data and more horizontal resolution presents an advanced tool for limnological investigations. We can suppose that with increased density of depth data, and hence horizontal resolution in the DBM, the overall accuracy of the morphometric variables will increase.

According to Håkanson and Jansson (1983), DBM's can be used for estimation of a sediment erosion area, as well as for estimation of sediment transportation and accumulation at the lake bottom. The models provide a source of information for the planning of monitoring of lake ecosystem. Another important application of the bathymetric model of Lake Ladoga can be in ecological modeling and remote sensing studies of the lake. Hence the limnological applications of the Lake Ladoga bathymetric model are multipurpose. However, for many lakes, similar applications are not yet possible because of a lack of digital bathymetric models. It is known that there is not sufficient bathymetric data for $1 / 3$ of the world's large lakes (Herdendorf 1982). Therefore, the DBM potential is not fully utilized and is a challenge for further investigations. This study furthers our understanding of the significance of the development lake digital models and the relationship of limnological processes with bottom depth distribution in a large lake.

\section{Acknowledgements}

This study was funded by the Ministry of Science and Higher Education of the Russian Federation No 0154-2019-0001 "A comprehensive as- 
sessment of the dynamics of ecosystems of Lake Ladoga and its reservoirs under the influence of natural and anthropogenic factors"

\section{References}

Alekin O.A. (ed.), 1984, Prirodnyye resursy bol'shikh ozer SSSR i veroyatnyye ikh izmeneniya (Natural resources of large lakes of the USSR and their probable changes), Izd. Nauka, Leningrad, 286 pp (in Russian).

Ambrosetti W., Barbanti L., 2002, Physical limnology of Italian lakes. 1. Relationship between morphometry and heat content, J. Limnol. 61(2): 147-157.

Baranov I., 1962, Limnologicheskiye tipy ozer SSSR (Limnological types of USSR lakes), Gidrometeoizdat, Leningrad, $273 \mathrm{pp}$ (in Russian).

Blais J., Kalff J., 1995, The influence of lake morphometry on sediment focusing, Limnol. Oceanogr. 40(3): 582-588.

Blenckner T., 2005, A conceptual model of climate-related effects on lake ecosystems, Hydrobiologia 533: $1-14$.

Chaplot V., Darboux F., Bourennane H., Leguedois S., Silvera N., Phachomphon K., 2006, Accuracy of interpolation techniques for the derivation of digital elevation models in relation to landform types and data density, Geomorphology 77(1-2): 126-141.

Chern'yeva F.A., 1966, Morfometricheskaya kharakteristika Ladozhskogo ozera (Morphometric characteristic of Lake Ladoga), [in:] Malinina T.I. (ed.), Gidrologicheskii rezhim i vodnyi balans Ladozhskogo ozera (The hydrological regime and water balance of Lake Ladoga), Izd. Nauka, Leningrad: 58-80 (in Russian).

Elo A.-R., 2007, Effects of climate and morphology on temperature conditions of lakes [Dissertation], University of Helsinki, Division of Geophysics, Helsinki, $56 \mathrm{pp}$.

Florinsky I.,1998, Accuracy of local topographic variables derived from digital elevation models, Int. J. Geogr. Inf. Sci. 12(1): 47-61.

Florinsky I., 2016, Digital terrain analysis in soil science and geology, Elsesevier / Academic Press, Amsterdam, 506 pp.

Gardner J., Mayer L.A., Clark J.E.H., 2000, Morphology and processes in Lake Tahoe (California-Nevada), Geol. Soc. Am. Bull. 112(5): 736-746.

Gorham E., 1964, Morphometric control of annual heat budgets in temperate lakes, Limnol. Oceanogr. 9(4): 525-529.

Håkanson L., 1981, A manual of lake morphometry, Springer, Heidelberg, $78 \mathrm{pp}$.

Håkanson L., 2005, The Importance of lake morphometry for the structure and function of lakes, Int. Rev. Hydrobiol. 90(4): 433-461.

Håkanson L., Jansson M.,1983, Principles of lake sedi- mentology, Springer, Berlin-New York-Heidelberg, $316 \mathrm{pp}$.

Herdendorf C.E., 1982, Large lakes of the world, J. Great Lakes Res. 8(3): 379-412.

Heritage G.L, Milan D.J, Large A.R.G., Fuller I.C., 2009, Influence of survey strategy and interpolation model of DEM quality, Geomorphology 112(3): 334-344.

Kourzeneva E, Asensio H, Martin E, Faroux S., 2012, Global gridded dataset of lake coverage and lake depth for use in numerical weather prediction and climate modeling, Tellus A. 64(1): $17 \mathrm{pp}$.

Krasovskii F.N., 1955, Izbrannye sochinenia. Tom 4 (Selected Works. Vol. 4), Geodezizdat., Moskva, 590 pp (in Russian).

Krause D., Menard H., 1965, Depth distribution and bathymetric classification of some sea-floor profiles, Mar. Geol.. 3(3): 169-193.

Lecours V., Dolan M.F.J., Micallef A., Lucieer V.L., 2016, A review of marine geomorphometry, the quantitative study of the seafloor, Hydrol. Earth Syst. Sci. 20: 3207-3244.

Masolov V., Popov S., Lukin V., Popkov A., 2010, The bottom topography and subglacial Lake Vostok water body, East Antarctica, Doklady Earth Sciences 433(2): 1092-1097.

Naumenko M.A., 1995, Novoye opredeleniye morfometricheskikh kharakteristik Ladozhskogo ozera (New estimation of morphometric characteristic of Lake Ladoga), Doklady RAN 345(4): 514-517 (in Russian, English summary).

Naumenko M.A., 2000, Novoye opredeleniye morfometricheskikh kharakteristik Onezhskogo ozera (New estimation of morphometric characteristics of Lake Onega), Doklady RAN 370(3): 393-396 (in Russian, English summary).

Naumenko M.A., 2008, Seasonality and trends in the Secchi disk transparency of Lake Ladoga, Hydrobiologia 599: 59-65.

Naumenko M.A., 2013, Glubiny i podvodnyi rel'yef (Depth and underwater relief), [in:] Rumyantsev V.A, Kondratiev S.A. (eds), Ladoga (Lake Ladoga), Izd. Nestor-Istoria, Sankt Peterburg, 84-90 (in Russian).

Naumenko M.A., 2015, Trekhmernoye izobrazheniye rel'yefa dna Ladozhskogo ozera (Three-dimensional image of bottom relief of Lake Ladoga), [in:] Rumyantsev V.A. (ed.), Ladozhskoye ozero i yego dostoprimechatel'nosti (Lake Ladoga and its sightseeing), Izd. Nestor-Istoria, Sankt Peterburg: 36-37(in Russian).

Naumenko M., Guzivaty V., 2010, Klimaticheskiye variatsii temperaturnogo rezhima Ladozhskogo ozera dlya perioda otkrytoy vody (Climatic variations of Lake Ladoga temperature regime for open water period), Regional'naya ekologiya 3: 104-108 (in Russian, English summary).

Naumenko M.A, Guzivaty V.V, Karetnikov S.G, 2007, Lake Ladoga as a typical dimictic lake, Limnol. Rev. 
7(2): 63-70.

Naumenko M.A., Karetnikov S.G., Guzivaty V.V., 2002, Seasonal evolution of the spatial distribution of water surface temperature in Lake Ladoga related to its morphometry, Doklady Earth Sciences, 386(7), 818820 (in Russian, English summary).

Naumenko M.A, Karetnikov S.G, Guzivaty V.V, Kryuchkov A.M, Pozdnyakov Sh.R., 2015, Lake Ilmen: Determining morphometric characteristics based on a digital model, Water Resources 42(5):572-579 (in Russian, English summary).

[NOAA] National Oceanic and Atmospheric Administration, 2020, Great Lakes Bathymetry [electronic resource], NOAA Satellite and Information Service, Boulder (Accessed 8 May 2020). Retrieved from https:// www.ngdc.noaa.gov/mgg/greatlakes/greatlakes. $\mathrm{html}$

Rumyantsev V.A, Drabkova V.G. (eds), 2002, Ladozhskoye ozero - proshloye, nastoyashcheye, budushcheye (Lake Ladoga - past, present, future), Izdat. Nauka, Sankt Peterburg, 328 pp (in Russian).

Sastre V, Loizeau J.L, Greinert J, Naudts L, Arpagaus P, Anselmetti F, Wildi W., 2010, Morphology and recent history of the Rhone River Delta in Lake Geneva (Switzerland), Swiss J. Geosci. 103(1): 33-42.

Salmaso N., Mosello R., Garibaldi L., Decet F., Brizzio M.C., Cordella P., 2003, Vertical mixing as a determinant of trophic status in deep lakes: a case study from two lakes south of the Alps (Lake Garda and Lake Iseo), J. Limnol., 62(Suppl. 1): 33-41.

Schertzer W.M., 2000, Digital bathymetry of Great Slave Lake, NWRI Contrib. No.00-257, National Water Research Institute, Burlington, $66 \mathrm{pp}$.

Schwab D.J., Sellers D.L., 1980, Computerized bathymetry and shorelines of the Great Lakes, NOAA Data Report. GLERL-16, Great Lakes Environmental Research Laboratory, Ann Arbor, 13 pp.
Selegei V., Dehandschutter B., Klerkx J., Vysotsky E. (eds), 2001, Physical and geological environment of Lake Teletskoye, Ann. Sci. Geol. 105: 1-310.

Sherstyankin P.P, Alekseev S.P, Abramov A.M, Stavrov K.G, De Batist M, Hus R, Canals M., Casamor J.L., 2006, Computer-based bathymetric map of Lake Baikal, Doklady Earth Science 408(4): 564-569 (in Russian, English summary).

Smith M.J., Paron P., Griffiths S. (eds), 2011, Geomorphological mapping. Methods and applications, Developments in Earth Surface processes 15, Elsevier, Amsterdam, 610 pp.

Sorokin A.I, Naumenko M.A., Veselova M.F., 1996, New morphometrical data of Lake Ladoga, Hydrobiologia 322: 65-67.

Subetto D., Davydova N., Rybalko A., 1998, Contribution to the lithostratigraphy and history of Lake Ladoga, Palaeogeogr. Palaeoclimatol. Palaeoecol. 140(1): 113-119.

Tilzer M.M., Serruya C. (eds), 1990. Large lakes. Ecological structure and function, Springer, Berlin-Heidelberg, $691 \mathrm{pp}$.

Tursunov E., Madibekov I., Kulebaev K., 2014, Sovremennye morfometricheskie kharakteristiki ozera Balkhash (Modern morphometric characteristics of Balkhash Lake), Uchennye zapiski RGGMU 34: 43-47 (in Russian, English summary).

Vidal J., Maclntyre S., McPhee-Shaw E.E., Shaw W.J., Monismith S. G., 2013, Temporal and spatial variability of the internal wave field in a lake with complex morphometry, Limnol. Oceanogr. 58(5): 1557-1580.

Wise S., 2000, Assessing the quality for hydrological applications of digital elevation models derived from contours, Hydrol. Process. 14(11-12): 1909-1929.

Wise S.M., 2007, Effect of differing DEM creation methods on the results from a hydrological model, Comput. Geosci. 33(10): 1351-1365. 